\title{
Latin America and the Challenges of Globalisation
}

\author{
Anca Gabriela Ilie and Dan Dumitriu \\ The Academy of Economic Studies, Faculty of International Business and Economics, \\ Bucharest, Romania
}

Correspondence should be addressed to: Anca Gabriela Ilie; ancaionescu2003@yahoo.com

Received date: 4 March 2014; Accepted date: 26 June 2014; Published date: 5 December 2014

Copyright (C) 2014. Anca Gabriela Ilie and Dan Dumitriu . Distributed under Creative Commons CCBY 3.0

\begin{abstract}
The main objective of this paper is to see how economic globalisation has affected the size of the state in Latin America, determining which of the effects - efficiency and compensation has been stronger in Latin America, a region that has joined the world economy gradually since the 1980s, with diverse experiences. In absolute terms, however, the state was more present in the economy in 2011 than in 2000 or 1980, helping reduce inequality, meaning that the compensation effect may exist, despite the analysis showing an ambiguous result. The results are generally confirmed by the quantitative analysis, with multiple linear crosssectional regressions and panel regression (with and without outliers) showing that indeed openness to trade, measured either through tariffs or through trade as share of GDP, is associated with a smaller state, with a (reliable) tariff coefficient. Our work in mainly conceived as a theoretical research grounded on statistical data. The conclusions of the case study point towards the existence of the efficiency effect, with growing trade associated with a smaller relative presence of the state in the economy. Globalisation does slightly reduce the size and the scope of the state in Latin America, but there is "an alternative view, based on global social justice and a balanced role for the government and the market.
\end{abstract}

Keywords: globalisation, state, Latin America, efficiency effect, compensation effect

\section{Introduction}

The volatility of the international financial system has been exacerbated by globalisation, transforming an initially limited default event into what is now a global financial crisis. This meant that globalisation and international economic integration have again become headline news, and their long-extolled benefits have been questioned, especially since it has been theorised that globalisation imposes constraints on state activity, meaning that it has less 'room to move', especially in turbulent times. With the growth of the world economy in the past half a century, one phenomenon has come to define our era, in economic, political, social and cultural terms - globalisation. Its effects have been felt in all countries that have decided to cooperate, rather than resist it, but its impact on state sovereignty and authority has been ambiguous.

The issue of state size and scope in the context of fluid borders is relevant because

Cite this Article as: Anca Gabriela Ilie and Dan Dumitriu (2014)," Latin America and the Challenges of Globalisation", Journal of Eastern Europe Research in Business and Economics , Vol. 2014 (2014), 
the state represents a country's pole of collective action for achievement of social harmonisation. Globalisation creates mobility for investors, multinationals, labour, goods and services, which can externally impose constraints on state action - the 'efficiency effect'. However, once state intervention is reduced, market forces generate an equilibrium with higher income inequality and poverty, and the people will demand redistribution - the 'compensation effect'. The magnitudes of these opposing effects are what determine the outcome in terms of state presence in the economy.

\section{Literature Review}

Stiglitz (2002, 2004) considers that globalisation can be beneficial, but its actual application and management have been defective, failing to achieve a balance between states and markets. Wolf (2004: 13) has a similar perspective of 'desirable' globalisation; in his view the state continues to be strong, in order to provide essential public goods: legal framework, security, property rights, executing international governance and expressing 'collective conscience'. Rodrik (1997: 65) admits there is a "tension between the consequences of globalisation and the requirements of maintaining the social legitimacy of free trade", but the state will not disappear: it can, at most, be slightly reduced or restructured. Zakaria (2008: 202) shares the fear of social disintegration, given that "growing inequality is the signature feature of the new era fuelled by a triple force - the knowledge economy, information technology, and globalisation". Essentially, the state will not disappear, but globalisation is "transforming the conditions under which state power is exercised" (Goksel, 2004: 10) and the state must adapt in order to face the various challenges of a globalised world (Yergin and Stanislaw, 2002).

With the demise of communism in the late 1980s and early 1990s, capitalism was left free to change the world; by then, capitalism had, however, become wilder, under the visionary leadership of the neoliberal paradigm and its pursuit of 'unfettered markets' (Friedman and Friedman, 1979). Countries that were beginning their transition towards capitalism were urged by global governing bodies, such as the International Monetary Fund (IMF) and the World Bank (WB) to embrace free markets both internally, by removing state intervention, and externally, by removing barriers to the free movement of goods, services, labour and, especially, capital (Stiglitz, 2002). While the benefits of free trade are generally undisputed, opening capital markets has produced pernicious cross-border externalities, especially if taking the form of 'gung-ho financial capitalism' (Bhagwati, 2004).

\section{Research Methodology}

First, the paper lays down the theoretical models and expectations, while the case study attempts to see whether the theory is respected, by combining a qualitative analysis of several political and economic events that have taken place since the 1980s, and especially between 2002 and 2012, with a quantitative analysis, employing both multiple linear regressions and panel regressions. Based on data from various sources, the authors attempt to assess, in a quantitative research, the relationship between growth in trade and state intervention (the efficiency effect), and the relationship between Gini coefficients evolution and state intervention, (the compensation effect). The conclusions of the case study point towards the existence of the efficiency effect, with growing trade associated with a smaller relative presence of the state in the economy. In absolute terms, however, the state was more present in the economy in 2011 than in 2000 or 1980 , helping reduce inequality, meaning that the compensation effect may exist, despite the analysis showing an ambiguous result. The simplest econometric model will use government expenditure (GVT EXP) as the dependent variable, and government revenue (GVT REV) and the level of applied tariffs (simple un-weighted average, or TARIFF) as independent variables. 
The panel regressions also uses GVT REV, TARIFF and GINI, but adds another variable, that of TRADE, taken as imports plus exports as percentage of GDP. The reason why the authors use two specifications with both TRADE and TARIFF is that while they both can be used as proxies for the level of globalisation to which a country has been subjected, TRADE is not only determined by tariffs, but also by the level of global trade and of internal growth, which might increase exports and imports regardless of the size of tariffs, so TRADE should be over and beyond TARIFF in terms of predictive power.

Some studies are focused on comparing the situation, adopted measures and results in different states or groups of countries, with the aim to identify some common elements that can be benchmarks of good practice in the field of efficiency or compensation effect of globalisation. (Dolls, Fuest and Peichl, 2010)

Changes in efficiency generated by globalisation. The need for state intervention to correct market imbalances

Any analysis of economic phenomena must include a description of the framework used for reference; given that globalisation is wide-reaching, ideological groups have attached different implications to state transformation by globalisation, in scope and size (Figure 1).

Fear that globalisation will reduce the state to minimal functions

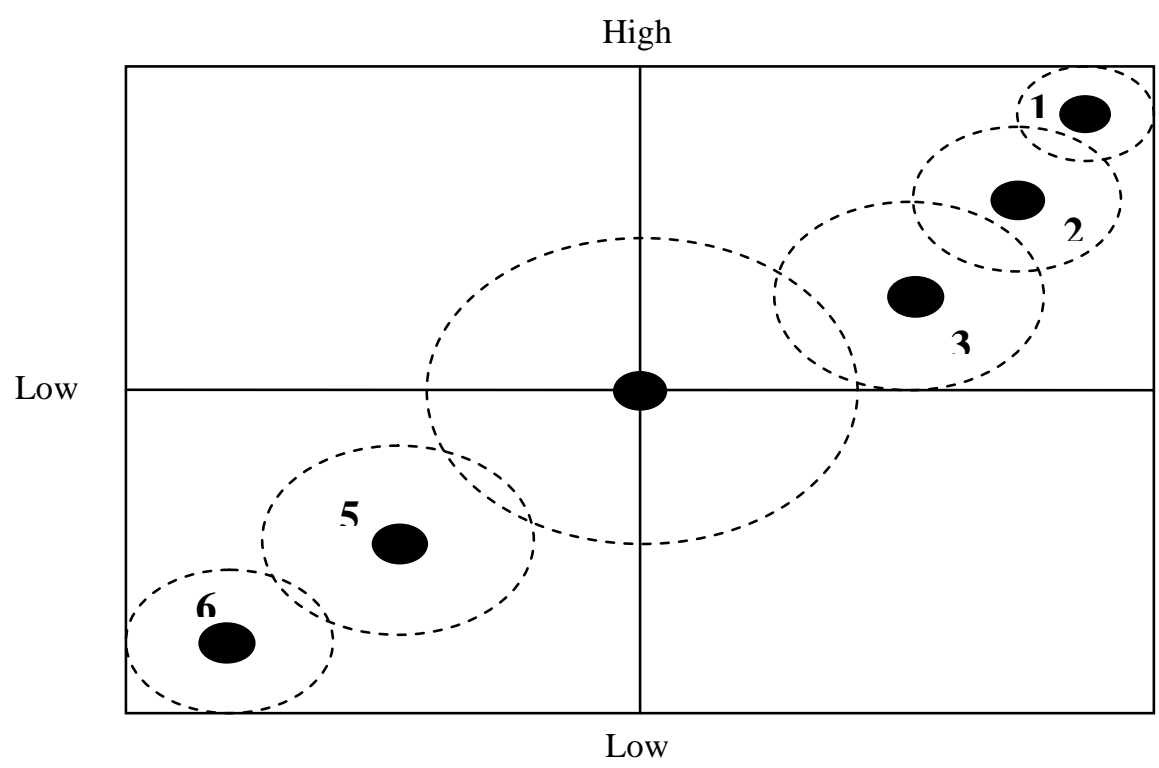

High

Desire for state intervention above the minimal state

Source: Authors

\section{Figure 1: Political/economic ideology groups and their perspective on globalisation and} the state

1) The first group consists of hard-line conservative nationalists, who expect a withering state, since globalisation "impoverishes the masses, destroys culture, undermines democracy, imposes Americanisation, lays waste the welfare state, ruins the environment and enthrones greed" (Wolf, 2004: 13). Behind "xenophobia and crude assertions of national interest and sovereignty" (Bhagwati, 2004: 25), they suggest backlash protectionism for cultural defence (Goldblatt et al, 1997): self reliance in trade and foreign investment inflows (Bhagwati, 
2004), despite the harmful effects of such practices, potentially overturning the initial welfare benefits (Schulze and Ursprung, 1999; Rodrik, 1997).

2) Hard-line socialists (generally radical leftists) also fear the reduction of state to minimal functions, and view globalisation as an "elite project", created by affinities in the interests and agendas of global capitalist classes, and states' foreign policies, leading to a system where dominant states impose rules on dominated states, but use strong protection for themselves (Gritsch, 2005).

3) Other consistent observers are the social democrats, who accept globalisation, but do not expect a collapse of national political power (Goldblatt et al, 1997).

4) Alternatively, having little fear of state reduction to minimal attributions and no particular desire for either minimal or total state intervention are what we referred to as 'centrists', or moderate thinkers.

5) Slightly leaning towards a state with minor functions are the classical liberals, who have a pragmatic view of government: there are some areas where intervention is appropriate, for instance in defence and security. Consequently, state disappearance is only a minor threat to them.

6) They are, however, differentiated from the neo-liberals, who believe that unattended markets reach efficient outcomes, rendering any government intervention unnecessary (Stiglitz, 2002).
For them, globalisation is an "irresistible and desirable force sweeping away frontiers, overturning despotic governments, undermining taxation, liberating individuals and enriching all it touches" (Wolf, 2004: 13). Since neoliberals only see the minimal state as justified, any move towards it is welcomed and desired (Goldblatt et al, 1997).

\section{Case Study}

The Latin American response to economic globalisation, a qualitative and quantitative analysis

5a). a brief qualitative analysis of globalisation and state involvement, 1980-present

After a severe debt crisis at the beginning of the 1980s (1980-1982), most countries entered periods of macroeconomic stabilisation, which involved, among others, trade liberalisation, after close to half a century of inward-oriented development, also known as import-substitution industrialisation (or ISI). This meant that the size and the scope of the government varied constantly, making an analysis of the entire period between 1980 and the present day (or 2012, as far as the data can reliably take us) an exercise likely to lead to ambiguous results and unlikely to shed light upon the subject, which is the impact of globalisation on the size and scope of state action. It is, however, necessary to mention that between 1980 and 2012 most countries in the region experienced a growth of trade (imports and exports) as a percentage of GDP (table 1).

Table 1: General Statistics on Latin American Countries (LAC)

\begin{tabular}{|c|c|}
\hline Country & $\begin{array}{c}\text { Growth in trade, } \\
\text { 1980-2012 } \\
\text { (\%GDP) }\end{array}$ \\
\hline Argentina & 331.125 \\
\hline Bolivia & 79.873 \\
\hline Brazil & 31.332 \\
\hline Chile & 66.817 \\
\hline Colombia & 16.915 \\
\hline
\end{tabular}




\begin{tabular}{|c|c|}
\hline Costa Rica & 41.190 \\
\hline $\begin{array}{c}\text { Dominican } \\
\text { Republic }\end{array}$ & 30.021 \\
\hline Ecuador & 32.053 \\
\hline El Salvador & -17.786 \\
\hline Guatemala & 22.334 \\
\hline Honduras & 27.762 \\
\hline Mexico & 195.818 \\
\hline Nicaragua & 69.604 \\
\hline Panama & -17.709 \\
\hline Paraguay & 217.001 \\
\hline Peru & 28.022 \\
\hline Uruguay & 80.222 \\
\hline Venezuela & 4.049 \\
\hline
\end{tabular}

Source: WTO Country Profiles, World Bank Data,2013.

On the one hand, there are countries whose efforts to become a larger international player are obvious: Argentina's trade as percentage of GDP rose more than 3 times (331\%), Paraguay's trade as percentage of GDP rose more than 2 times (217\%) and Mexico's trade as percentage of GDP grew almost 2 times (195\%). On the other hand, some countries have lost some trade as percentage of GDP or have only integrated slowly: among them we can count Panama and El Salvador (a reduction of trade in GDP by $17 \%$ for both) and Venezuela (a 4\% growth). (Acemoglu and Robinson, 2012)..
Mexico is one of the countries that have been active in integration efforts, especially with the introduction of the North American Free Trade Agreement (NAFTA) in 1995, partnering with the United States and Canada. While it is true that the Mexican economy has benefited from increased trade and revenues, there are reasons of concern. (Chomsky, 2010)

Brazil and Argentina were also affected by globalisation, which helped to transmit financial crises across the world, via capital market liberalisation, and both countries suffered at the end of the 1990s, although Argentina's collapse did not come until 2001 (Stiglitz, 2012: 42). 


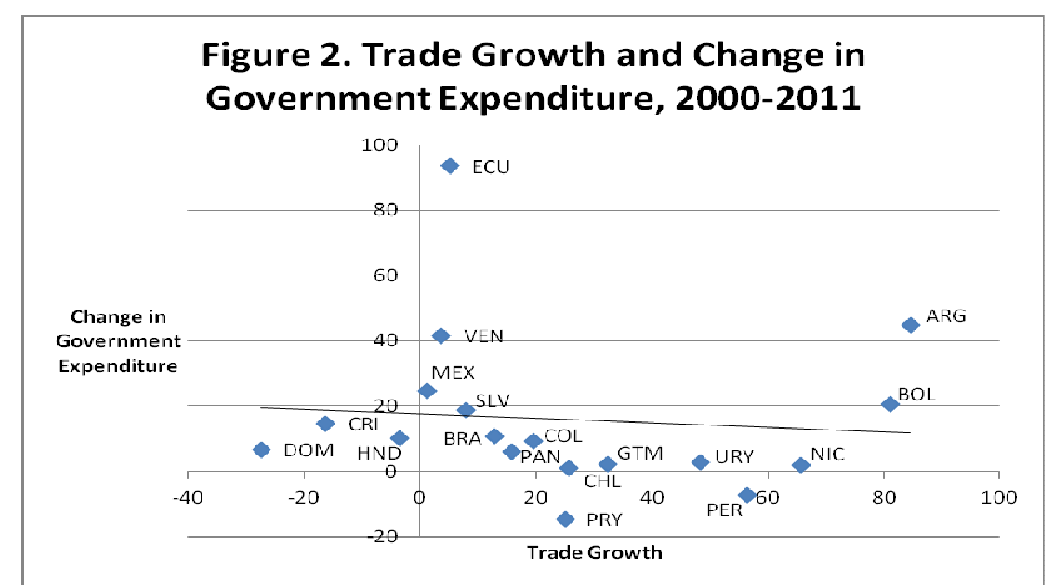

Source:IMF World Economic Outlook Database, April 2013

The efforts that countries have made in order to achieve integration are seen in the reduction in applied tariffs between 2000 and 2012: the average (un-weighted) applied tariff in Latin America dropped from 14.75 percent to 8.26 percent in 12 years.

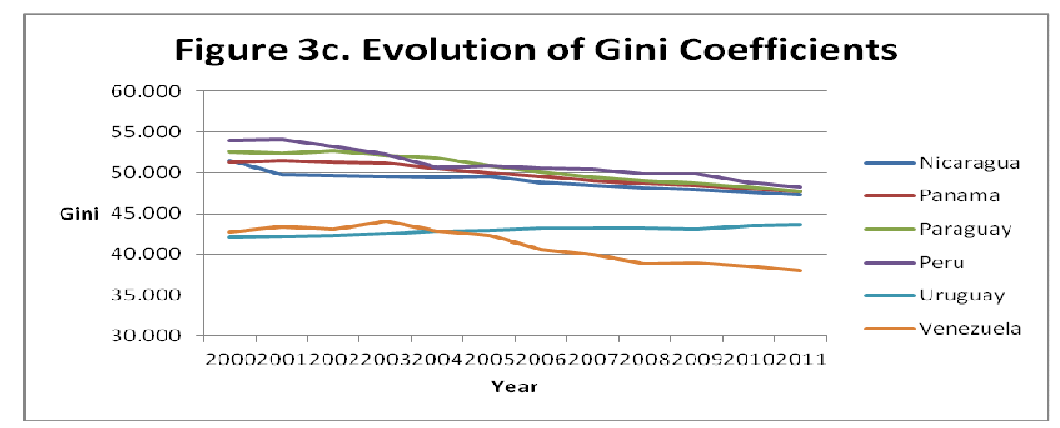

Source: Standardised World Income Inequality Database, version 3.1, June 2013.

As table 2 shows, the result has been growing trade (especially in relation to GDP), although the pace has been slower in the period under evaluation since the bulk of growth took place after adhering to the WTO. The correlation between tariffs and trade is not particularly strong, of only 0.29 , perhaps given that, cateris paribus, economic growth tends to increase imports and exports, regardless of tariffs.

Table 2: Tariff changes and trade growth, 2000-2011

\begin{tabular}{|c|c|c|c|c|c|c|}
\hline Country & $\begin{array}{l}\text { Applied } \\
\text { Tariff } \\
\mathbf{2 0 0 0}\end{array}$ & $\begin{array}{l}\text { Applied } \\
\text { Tariff } \\
\mathbf{2 0 1 2}\end{array}$ & $\begin{array}{l}\text { Change } \\
\text { in } \\
\text { Tariffs }\end{array}$ & $\begin{array}{l}\text { Trade } \\
\text { growth } \\
\text { to peak }\end{array}$ & $\begin{array}{l}\text { Trade } \\
\text { growth } \\
\text { to 2012 }\end{array}$ & \\
\hline Argentina & 15.05 & 13.61 & -1.44 & 101.050 & 84.581 & \\
\hline Bolivia & 9.32 & $10.31^{*}$ & 0.99 & 74.273 & 80.996 & \\
\hline Brazil & 15.55 & 13.68 & -1.87 & 20.500 & 12.853 & \\
\hline Chile & 8.98 & 5.98 & -3 & 35.593 & 25.795 & \\
\hline Colombia & 12.23 & 8.35 & -3.88 & 13.848 & 19.635 & \\
\hline Costa Rica & 5.64 & 5.35 & -0.29 & 7.456 & -16.274 & \\
\hline
\end{tabular}




\begin{tabular}{|c|c|c|c|c|c|c|}
\hline $\begin{array}{c}\text { Dominican } \\
\text { Republic } \\
\end{array}$ & 8.37 & 7.03 & -1.34 & -20.776 & -27.377 & \\
\hline Ecuador & 11.92 & 10.06 & -1.86 & 6.640 & 5.151 & \\
\hline $\begin{array}{c}\text { El } \\
\text { Salvador }\end{array}$ & 7.08 & 5.88 & -1.2 & 7.940 & 7.964 & \\
\hline Guatemala & 42.55 & 5.54 & $\begin{array}{c}- \\
37.01^{* *}\end{array}$ & 34.319 & 32.324 & \\
\hline Honduras & 7.28 & 5.58 & -1.7 & 12.474 & -3.373 & \\
\hline Mexico & 17.9 & 8.1 & -9.8 & -9.378 & 1.248 & \\
\hline Nicaragua & 42.63 & 5.56 & $\begin{array}{c}- \\
37.07^{* *}\end{array}$ & 39.969 & 65.722 & \\
\hline Panama & 8.1 & 6.85 & -1.25 & 11.075 & 15.793 & \\
\hline Paraguay & 13.16 & 10.18 & -2.98 & 26.024 & 25.188 & \\
\hline Peru & 13.38 & 3.67 & -9.71 & 54.699 & 56.438 & \\
\hline Uruguay & 13.91 & 10.53 & -3.38 & 69.444 & 48.267 & \\
\hline Venezuela & 12.41 & 12.47 & 0.06 & 12.865 & 3.721 & Correlation \\
\hline Average & 14.748 & 8.263 & -6.485 & 27.667 & 24.370 & -0.290 \\
\hline
\end{tabular}

Sources: WTO Country Profiles, World Bank Data, IMF World Economic Outlook Database, WTO Tariff Analysis.

* For Bolivia, the latest available applied tariff is that for 2009.

** The reduction in tariffs is so large given that a very high short-term, reactionary tariff was practiced in 2000 .

This short qualitative analysis has revealed that the theory has not been entirely respected: while trade does tend to reduce the extent of state activity (rather mildly), there have been major strides in reducing inequality. The years between 2000 and 2012 have shown a fairly stable growth, and the growth of trade has continued; as such, globalisation seems to have been fairly beneficial for Latin American countries, although several crisis episodes have been strongly connected with the failures of managing globalisation so as to avoid contagion.

\section{5b) a quantitative analysis of the efficiency and compensation effects, 2000-2012}

Based on data from various sources, including World Bank data, WTO Country Profiles, WTO Tariff Analysis, the April 2013 IMF World Economic Outlook Database and the Standardised World Income Inequality Database, we attempt to assess in a quantitative manned the relationship between growth in trade and state intervention (the efficiency effect), and the relationship between Gini coefficients evolution and state intervention, (the compensation effect). The first step is to evaluate the impact of lower tariffs on the level of government expenditure (used as a proxy for state intervention throughout this section), by running two fairly simple cross section regressions, for 2000 and 2012 (the largest interval for which data is available), with the ultimate goal of finding whether the coefficient changes, and in what direction. The countries involved are the 18 Latin American Countries (LAC) . (table 1).

The simplest model will use government expenditure (GVT EXP) as the dependent variable, and government revenue (GVT REV) and the level of applied tariffs (simple un-weighted average, or TARIFF) as independent variables. Government expenditure and revenue are used as percentage of GDP, and tariffs as percentage of the import prices: there is no clear expectation for the effect of tariffs on government revenue because on the one hand higher tariffs provide revenues on imports, but on the other hand reduce the 
size of the internal market, lowering revenues from taxation. The data for 2012 does signal that the model might suffer from multicollinearity, and that higher tariffs are actually associated with higher revenues, with a correlation of 0.71 . The model used is:
GVT FXP $=\alpha+\beta *$ IXVTRFV $+\gamma \leqslant$ TARIFF $+\varepsilon$

The results for this regression are available in Table 4.

Table 3: Results for the regression

\begin{tabular}{|l|c|c|c|c|c|c|}
\hline & \multicolumn{5}{|c|}{ Dependent variable is GVT EXP } \\
\hline & \multicolumn{2}{|c|}{$\mathbf{2 0 0 0}$} & \multicolumn{2}{c|}{$\mathbf{2 0 1 2}$} \\
\hline & $(\mathbf{1})$ & & $\mathbf{( 2 )}$ & & (3) & (4) \\
\hline Intercept & $24.4328^{*}$ & $4.4130^{* * *}$ & & $7.8559^{* * *}$ & 1.4587 \\
\hline & $(2.4087)$ & & $(2.1041)$ & & $(3.9282)$ & $(2.1867)$ \\
\hline & & & & & & \\
\hline GVT REV & - & & $0.8797^{*}$ & & - & $0.7743^{*}$ \\
\hline & - & & $(0.0484)$ & & - & $0.1119)$ \\
\hline & & & & & & \\
\hline TARIFF & -0.0489 & & 0.0111 & & $2.3746^{*}$ & $0.7756^{* *}$ \\
\hline & $0.1337)$ & & $(0.0843)$ & & $0.4431)$ & $0.3215)$ \\
\hline & & & & & & \\
\hline R Square & 0.1337 & & 0.8800 & & 0.6422 & 0.9146 \\
\hline Regression F & 0.0083 & & $54.9973^{*}$ & & $28.7215^{*}$ & $80.3650^{*}$ \\
\hline Observations & 18 & & 18 & & 18 & 18 \\
\hline
\end{tabular}

The simple regression, using only TARIFF, for 2000 is not a valid specification, but it becomes valid once government revenue is introduced, as the logical determinant of government spending, since there is a limit to how much a government can spend over its revenues. For 2012, both specifications are valid; when revenues are also taken into account, the level of tariffs is positively related to state expenditures: a 1 percent increase in tariffs leads to a 0.77 percent increase in government expenditure, in other words openness to trade is associated with lower government spending.

In order to also see if the compensation effect manifests itself, we run a multiple regression, which uses alternatively the Gini for that specific year, or a lagged Gini, from the previous year. The explanation for the latter independent variable is the fact that government is likely to model its spending after seeing the results of the previous years, and a lagged variable ensures that causality is not affected. The model is, thus:

$$
G V T E X P=\alpha+\beta \leqslant G V T R E V+\gamma * T A R I F F+\delta *(L A G) G I N I+\varepsilon
$$

Specification (1) of table 6 is valid, but neither the coefficient of TARIFF nor of GINI is significant at the usual significance levels. For 2011, specification (2), using that year's specific Gini is valid, and the
Gini coefficient is significant at the 95 percent confidence level: a growth of one point in the Gini leads to a 0.4 reduction in government spending, meaning that there is little manifestation of the compensation effect, in a cross-country perspective. 
Table 4: Multiple regression with GINI

\begin{tabular}{|c|c|c|c|}
\hline & \multicolumn{3}{|c|}{ Dependent variable is GVT EXP } \\
\hline & \multirow{2}{*}{$\begin{array}{c}2000 \\
(1)\end{array}$} & \multicolumn{2}{|c|}{2012} \\
\hline & & (2) & (3) \\
\hline & & & \\
\hline \multirow[t]{2}{*}{ Intercept } & -0.1393 & $21.5403^{* *}$ & $22.7415^{* *}$ \\
\hline & $(7.4527)$ & $(8.9937)$ & $(9.1269)$ \\
\hline & & & \\
\hline \multirow[t]{2}{*}{ GVT REV } & $0.8843^{*}$ & $0.8389 *$ & $0.8459^{*}$ \\
\hline & $(0.0863)$ & $(0.1028)$ & $(0.1022)$ \\
\hline & & & \\
\hline \multirow[t]{2}{*}{ TARIFF } & 0.0042 & 0.4291 & 0.4116 \\
\hline & $(0.0505)$ & $(0.3219)$ & $(0.3195)$ \\
\hline & & & \\
\hline \multirow[t]{2}{*}{ GINI } & 0.0919 & $-0.4052^{* *}$ & - \\
\hline & $(0.1440)$ & $(0.1773)$ & - \\
\hline & & & \\
\hline \multirow[t]{2}{*}{ LAG GINI } & - & - & $-0.4294^{* *}$ \\
\hline & - & - & $(0.1801)$ \\
\hline & & & \\
\hline R Square & 0.8834 & 0.9378 & 0.9393 \\
\hline Regression F & $35.3507 *$ & $70.4160^{*}$ & $72.2112^{*}$ \\
\hline Observations & 18 & 18 & 18 \\
\hline
\end{tabular}

Note: standard errors in brackets; valid at the *0.01 significance level; ${ }^{* *} 0.05$ significance level; ${ }^{* * *} 0.1$ significance level.

Source: own calculations based on data obtained from sources

In order to benefit from a larger sample and to take into consideration not only cross-country effects, but also evolutions in time, we run a panel regression, spanning the period 2000-2012 in the 18 Latin American countries. The model also uses GVT REV, TARIFF and GINI, but adds another variable, that of TRADE, taken as imports plus exports as percentage of GDP. The reason why we use two specifications with both TRADE and TARIFF is that while they both can be used as proxies for the level of globalisation to which a country has been subjected, TRADE is not only determined by tariffs, but also by the level of global trade and of internal growth, which might increase exports and imports regardless of the size of tariffs, so TRADE should be over and beyond TARIFF in terms of predictive power. The weakly negative relationship between them (as expected), given by a correlation coefficient of -0.275 , means both coefficients might be inefficient, since they interfere with each other (slightly). The model thus becomes:

$$
G V T E X P_{i t}=\alpha+\beta * G V T R E V_{i t}+\gamma * T_{A R I F F_{i t}}+d * G N I_{i t}+\lambda * T R A D E_{i t}+\varepsilon_{i \pm}
$$


Table 5: Panel regression, years 2000-2012

\begin{tabular}{|c|c|c|c|c|}
\hline & \multicolumn{4}{|c|}{ Dependent variable is GVT EXP } \\
\hline & \multicolumn{2}{|c|}{ With outliers } & \multicolumn{2}{|c|}{ Without outliers } \\
\hline & (1) & (2) & (3) & $(4)$ \\
\hline & & & & \\
\hline \multirow[t]{2}{*}{ Intercept } & $11.8023^{*}$ & $12.6128^{*}$ & $12.1137 *$ & $12.6364^{*}$ \\
\hline & $(2.9150)$ & $(2.9226)$ & $(3.0000)$ & $(3.0345)$ \\
\hline & & & & \\
\hline \multirow[t]{2}{*}{ GVT REV } & $0.9338^{*}$ & $0.9187^{*}$ & $0.9002^{*}$ & $0.8987^{*}$ \\
\hline & $(0.0288)$ & $(0.0296)$ & $(0.0327)$ & $(0.0328)$ \\
\hline & & & & \\
\hline \multirow[t]{2}{*}{ GINI } & $-0.1879^{*}$ & $-0.1754^{*}$ & $-0.2013^{*}$ & $-0.1907^{*}$ \\
\hline & $(0.0566)$ & $(0.0566)$ & $(0.0581)$ & $(0.0589)$ \\
\hline & & & & \\
\hline \multirow[t]{2}{*}{ TARIFF } & $0.0642^{*}$ & $0.0500^{* *}$ & $0.1855^{*}$ & $0.1415^{* * *}$ \\
\hline & $(0.0241)$ & $(0.0250)$ & $(0.0694)$ & $(0.0798)$ \\
\hline & & & & \\
\hline \multirow[t]{2}{*}{ TRADE } & - & $-0.0131^{* *}$ & - & -0.0084 \\
\hline & - & $(0.0066)$ & - & $(0.0075)$ \\
\hline & & & & \\
\hline R Square & 0.8503 & 0.8532 & 0.8510 & 0.8520 \\
\hline Regression F & $372.9528^{*}$ & $284.8210^{*}$ & $354.1259^{*}$ & $266.2525^{*}$ \\
\hline Observations & 201 & 201 & 190 & 190 \\
\hline
\end{tabular}

Note: standard errors in brackets; valid at the ${ }^{*} 0.01$ significance level; ${ }^{* *} 0.05$ significance level; ${ }^{* * *} 0.1$ significance level.

Source: own calculations based on data obtained from sources

Specification (1) uses all the years for which applied tariffs are available, and is extremely significant, all coefficients being significant at the $99 \%$ confidence level. Higher tariffs are again positively related to government expenditures, a one percentage point increase in tariffs raises government expenditures by 0.06 percent (of GDP), while GINI also maintains its negative coefficient, with a one point increase in the Gini leading to lower state spending. Specification (2) introduces TRADE, which lowers the magnitude of the other variables' impact on government expenditures, but maintains the explanatory power of the model. The coefficient of TRADE is negative: higher trade levels with one percent (of GDP), lead to a reduction in state spending by 0.013 percent (of GDP). If we associate increased trade with increased foreign company presence on the internal market, then we can see that the efficiency effect is at work, and there are more constraints on government spending.

Specifications (3) and (4) are similar to those just analysed, but reduce the data set by excluding years where average applied tariffs were a circumstantial response to market conditions: they sometimes exceeded 40 percent, while values before and after where much lower, usually in the tens. The coefficient signs are similar to the ones in the previous two specifications, but that of TRADE is not significant any more at the usual confidence levels, which casts doubt on the previous confirmation of the efficiency effect, through trade. 
Table 7 shows another set of regression specifications, this time using a lagged Gini variable in order to respect causality. The downside of such a (general) specification is the loss of observations from the first year, or 2000. This effectively reduces the sample to 183 observations (174 without outliers), which is still a fairly large sample.

Table 6: Panel regression, years 2000-2012

\begin{tabular}{|c|c|c|c|c|}
\hline & \multicolumn{4}{|c|}{ Dependent variable is GVT EXP, Lagged Gini } \\
\hline & \multicolumn{2}{|c|}{ With outliers } & \multicolumn{2}{|c|}{ Without outliers } \\
\hline & $(1)$ & $(2)$ & (3) & $(4)$ \\
\hline \multirow[t]{2}{*}{ Intercept } & $14.0763^{*}$ & $14.8111^{*}$ & $14.7390^{*}$ & $15.1872^{*}$ \\
\hline & $(3.1236)$ & $(3.1370)$ & $(3.2275)$ & $(3.2670)$ \\
\hline \multirow[t]{2}{*}{ GVT REV } & $0.9365^{*}$ & $0.9229^{*}$ & $0.9051^{*}$ & $0.9041^{*}$ \\
\hline & $(0.0302)$ & $(0.0310)$ & $(0.0343)$ & $(0.0343)$ \\
\hline & & & & \\
\hline \multirow[t]{2}{*}{ LAG GINI } & $-0.2362 *$ & $-0.2248^{*}$ & $-0.2557 *$ & $-0.2469 *$ \\
\hline & $(0.0607)$ & $(0.0607)$ & $(0.0624)$ & $(0.0632)$ \\
\hline \multirow[t]{2}{*}{ TARIFF } & $0.0705^{*}$ & $0.0577^{* *}$ & $0.1824^{* *}$ & $0.1452^{* * *}$ \\
\hline & $(0.0267)$ & $(0.0276)$ & $(0.0755)$ & $(0.0861)$ \\
\hline & & & & \\
\hline \multirow[t]{3}{*}{ TRADE } & - & $\begin{array}{c}- \\
0.0120^{* * *}\end{array}$ & - & -0.0072 \\
\hline & - & $(0.0070)$ & - & $(0.0079)$ \\
\hline & & & & \\
\hline R Square & 0.8526 & 0.8549 & 0.8546 & 0.8553 \\
\hline Regression F & 345.0851* & 262.2817* & 332.9985* & $249.6874 *$ \\
\hline Observations & 183 & 183 & 174 & 174 \\
\hline
\end{tabular}

Note: standard errors in brackets; valid at the ${ }^{*} 0.01$ significance level; ${ }^{* *} 0.05$ significance level; ${ }^{* * *} 0.1$ significance level.

Source: own calculations based on data obtained from sources

The upside of the model is that it makes more sense in economic and logical terms, and that it removes several estimated values for the 2012 Gini, since the year
2011 now uses the Gini from 2010, and there are less estimated values. The model, then, appears as follows:

$$
G V T E X P_{i t}-u+\beta=G V T R E V_{i t}+\gamma=T A R I P P_{i t}+\delta * L A G G I N I_{i t}+\lambda * T F A D E_{i t}+\varepsilon_{i t}
$$

Before eliminating the outliers (extreme values of average applied tariffs), all the signs are as expected, but LAG GINI seems to have an even larger effect on government spending: in specification (1), with a 99 percent confidence, a 1 point reduction in the Gini now results in a 0.236 percent (of GDP) reduction in government spending. In specification (2), after TRADE is introduced the coefficient of TARIFF becomes smaller, but they both act in the same direction: openness is associated with less state spending.

Once the outliers are removed, specifications (3) and (4) show the same type of relationship: the coefficient of TARIFF becomes larger and it is now significant at 95 or 90 percent, respectively. A one percent rise in the 
average applied tariff leads to an increase in state spending of between 0.15 and 0.18 percent (of GDP). However, the coefficient of TRADE is no longer significant, and the presence of the variable tends to reduce the magnitude of the effect of tariffs on government spending. For all four panel specifications in table 6 , the $\mathrm{R}^{2}$ remains around the value of 0.85 , showing that the model has a good explanatory and predictive power.

With the recognition that some components of state spending cannot be drastically reduced in a short time period, it is natural to assume some temporal correlation in the GVT EXP variable. A more complete model introduces a lag GVT EXP variable, as follows:

$$
\begin{aligned}
\text { GVT EXP } & =\alpha+\beta \leqslant G V T E X P_{i t-1}+\gamma \leqslant G V T R E V_{i t}+\delta \leqslant(L A G) G_{i N I_{i t}}+\lambda \leqslant \text { TARIFF } \\
& +\tau \leqslant T R A D E_{i t}+\varepsilon_{i t}
\end{aligned}
$$

\begin{tabular}{|c|c|c|c|c|}
\hline & \multicolumn{4}{|c|}{ Dependent variable is GVT EXP (t) } \\
\hline & \multicolumn{2}{|c|}{ With outliers } & \multicolumn{2}{|c|}{ Without outliers } \\
\hline & $(1)$ & $(2)$ & $(3)$ & (4) \\
\hline \multirow{2}{*}{ Intercept } & $52971 *$ & $53827 *$ & $5.6261 *$ & $56381 *$ \\
\hline & 2.0105 & 2.0418 & 2.0889 & 2.1215 \\
\hline & & & & \\
\hline \multirow[t]{2}{*}{$\begin{array}{c}\text { GVT EXP (t- } \\
\text { 1) } \\
\end{array}$} & $0.7349 *$ & $0.7332^{*}$ & $0.7284^{*}$ & $0.7283^{*}$ \\
\hline & $(0.0440)$ & $(0.0446)$ & $(0.0454)$ & $(0.0457)$ \\
\hline & & & & \\
\hline \multirow[t]{2}{*}{ GVT REV (t) } & $0.2930^{*}$ & $0.2931^{*}$ & $0.2932 *$ & $0.2933^{*}$ \\
\hline & $(0.0429)$ & $(0.0430)$ & $(0.0439)$ & $(0.0442)$ \\
\hline & & & & \\
\hline \multirow[t]{2}{*}{ GINI } & $-0.1126^{*}$ & $-0.1116^{*}$ & $-0.1191^{*}$ & $-0.1188^{*}$ \\
\hline & $(0.0385)$ & $(0.0388)$ & $(0.0400)$ & $(0.0405)$ \\
\hline \multirow[t]{2}{*}{ TARIFF } & $0.0292^{* * *}$ & 0.0280 & 0.0443 & 0.0434 \\
\hline & $(0.0170)$ & $(0.0176)$ & $(0.0489)$ & $(0.0554)$ \\
\hline & & & & \\
\hline \multirow[t]{2}{*}{ TRADE } & - & -0.0012 & - & -0.0002 \\
\hline & - & $(0.0045)$ & - & $(0.0051)$ \\
\hline & & & & \\
\hline R Square & 0.9418 & 0.9419 & 0.9414 & 0.9414 \\
\hline Regression F & $720.4862^{*}$ & 573.3895* & 679.2720* & $540.2065^{*}$ \\
\hline Observations & 183 & 183 & 174 & 174 \\
\hline & & & & \\
\hline
\end{tabular}

Table 7: Panel Regression, with lagged GVT EXP

Note: standard errors in brackets; valid at the *0.01 significance level; ${ }^{* *} 0.05$ signficance level; ${ }^{* * *} 0.1$ significance level.

Source: own calculations based on data obtained

In all, the results from the cross-section regressions are verified by those from the panel regression, which shows that the models are consistent and the results are fairly robust. In terms of limitation, it is necessary to mention that the period of analysis might be fairly short, of only 13 years. Considering that Latin America generally embarked on a path of trade liberalisation in the 1980s and early 1990s and that usually the effect is stronger in the short run, the period we study might have 
only subdued effects, because it does not capture the most relevant events.

For our purposes, however, the variables of TARIFF and TRADE, as well as GINI are enough to give a relatively clear picture of the effects of globalisation on the size and scope of the state. Here, we have additional limitations: the state does not only spend as a measure of authority, but it also has a strong regulatory role, which we have not explored in this paper.

\section{Conclusion}

Globalisation tends to allow countries to specialise in the resource they are most abundant in, which means that developed countries should produce capital-intensive goods (including, and especially, human capital), and developing countries should produce labour-intensive goods. Consequently, in the rich countries the demand for highly skilled workers would increase, meaning that income gaps would widen; in the poor countries the unskilled workers would be demanded, meaning that their wage premiums will increase, and the income gap would eventually narrow.

Latin America, once a troubled region in political and economic terms, has largely stabilised in macroeconomic terms, allowing it to achieve a fairly stable (and strong) growth and a reduction in inequality. The qualitative analysis we perform shows that trade as percentage of GDP has grown more than government expenditures as percentage of GDP, showing that the efficiency effect is at work. The results are generally confirmed by the quantitative analysis, with multiple linear cross-sectional regressions and panel regression (with and without outliers) showing that indeed openness to trade, measured either through tariffs or through trade as share of GDP, is associated with a smaller state, with a (reliable) tariff coefficient varying between 0.07 and 0.03 . The Gini coefficients, used to model inequality, point to inequality leading a smaller state, with a coefficient finally stabilising at around -0.11. Several specifications have been employed, with similar, consistent results, showing that the relationship is fairly robust.

The model used for regression analysis can be improved to take into account issues of multicollinearity, of missing variables and of temporal correlation of the errors. For our purposes - showing the direction of the effect of globalisation on state size - the model has been sufficient, but in order to pinpoint the magnitude of the effect, a better model is necessary. The qualitative analysis could also be improved by expanding the period and analysing the impact of globalisation immediately after a larger opening episode, such as the period immediately after 1995, when Mexico joined the North American Free Trade Agreement. However, the moderate, social democratic governments of the region seem to have effectively countered the negative effects of globalisation, and continue in the same vein.

The role of the state will be to provide public goods, and to keep an eye on regulation and surveillance of financial systems, tax collection, environmental management, investments in education and health, a stable legal framework, basic social safety nets and society (Yergin and Stanislaw, 2002). The emphasis must be placed on flexibility and adaptability, but it is clear that mobility is not yet complete, and that the state will not disappear: "Distance will always matter, because we are physical. Because distance always matters, so does space. Because space always matters, so does territorial control. Because territorial control matters, so do states. For this simple reason, economic processes will not compel the death of states" (Wolf, 2004: 16).

Making government more responsive to and responsible before its citizens is essential, keeping in mind that the economy should also have very strong markets. Latin America has moved in this direction, reducing poverty and inequality, at the same time that its countries become large international players (like Brazil and Mexico, for instance). The Latin American model thus seems to have worked well, despite its various shortcomings and the 
violent fluctuations it has experienced in the past. Now, Latin America seems set for growth in a globalised world, based on an inclusive type of growth, breaking away from its extractive institutions (Acemoglu and Robinson, 2012). The final conclusion is globalisation does slightly reduce the size and the scope of the state in Latin America, but there is "an alternative view, based on global social justice and a balanced role for the government and the market. It is for that vision that we should be striving" (Stiglitz, 2004: 319).

\section{References}

1. Acemoglu, D. and Robinson, J.A. (2012). Why Nations Fail: The Origins of Power, Prosperity, and Poverty, New York: Crown Business, 213-245.

2. Atkinson, A.B. and Morelli (2011). "Economic Crises and Inequality", United Nations Development Programme, Human Development Research Paper 2011/06, http://hdrstats.undp.org/sites/default/file s/hdrp_2011_06.pdf.

3. Berg, A.G. and Ostry, J.D. (2011). "Inequality and Unsustainable Growth: Two Sides of the Same Coin?", IMF Staff Discussion Note, SDN/11/08, http://www.imf.org/external/pubs/ft/sdn /2011/sdn1108.pdf.

4. Chomsky, N. (2010). Hopes and Prospects. London: Penguin Books, 116 128.

5. Friedman, T.L. (2005). The World is Flat. The Globalised World in the TwentyFirst Century. New York: Penguin Books, $228-243$.

6. Goksel, N.K. (2011). "Globalisation and the State", Perceptions, Journal of International Affairs, January, vol. 12, 1-16.

7. Goldblatt, D., Held, D., McGrew, A. and Perraton, A. (1997). "Economic Globalisation and the Nation-State: Shifting Balances of Power", Alternatives: Global, Local, Political, vol. 22(3): 269-285.
8. Gritsch, M. (2005). "The Nation-State and Economic-Globalisation: Soft GeoPolitics and Increased State Autonomy?", Review of International Political Economy, vol. 12(1): 1-25

9. International Monetary Fund (2013) "Promoting a more secure and stable global economy", IMF Annual Report, https://www.imf.org/external/pubs/ft/ar /2013/eng/pdf/ar13_eng.pdf

10. Krugman, P. (2009). The Return of Depression Economics and the Crisis of 2008. London: W.W. Norton \& Company, http://gendocs.ru/docs/14/13637/conv_1 /file1.pdf, 30-56.

11. Panitch, L. (1994). "Globalisation and the State", The Socialist Register, vol. 30, 60-93,

http://socialistregister.com/index.php/srv /article/view/5637\#.U144N_l_trU.

12. Rodrik, D. (1998) "Where did all the Growth Go? External Shocks, Social Conflict and Growth Collapses", National Bureau of Economic Research, Working Paper No. 6350 , published in Journal of Economic Growth vol 4, http://www.nber.org/papers/w6350, 358412.

13. Stiglitz, J.E., (2003) "Globalisation and the Economic Role of the State in the New Millennium", Industrial and Corporate Change, vol. 12(1): 3-26, http://policydialogue.org/files/publication s/Globalization_and_Role_of_State_Stiglitz. pdf.

14. Stiglitz, J.E. (2012) The Price of Inequality., Norton Company, USA, New York, 52-70.

15. Tirwall, A.P., Pancheco-Lopez, P (2008) - "Trade Liberalisations and the Poverty of Nations", EdwardElgar Publishing Limited, UK ,107 - 130

16. Wolf, M. (2004) - Why Globalisation Works. London: Yale University Press, http://yalepress.yale.edu/yupbooks/excer pts/wolf_globalization.pdf. 
17. Wood, A. (2002) - "Globalisation and Wage Inequalities: A Synthesis of Three Theories", Review of World Economics (Weltwirtschaftliches Archiv), vol. 138(1): 54-82.

18. World Bank (2013) - "End extreme poverty. Promote shared prosperity", World Bank

Annualreport,https://openknowledge.worl dbank.org/bitstream/handle/10986/1609 1/9780821399378.pdf?sequence $=1$
19. World Trade Organization (2013) "Factors Shaping the future of world trade",

http://www.wto.org/english/res_e/books p_e/world_trade_report13_e.pdf

20. Yergin, D. and Stanislaw, J. (2002) - The Commanding Heights: The Battle for the World Economy. New York: Touchstone, 338-345. 